\title{
PENGARUH LINGKUNGAN KERJA DAN STRES KERJA TERHADAP KINERJA KARYAWAN BAGIAN PRODUKSI PADA PT BENING BIG TREE FARM DI DESA SIBANG BADUNG
}

\author{
I Made Adi Suwandana ${ }^{1}$ \\ Desak Nyoman Werdiasih ${ }^{2}$ \\ ${ }^{1,2}$ Fakultas Ekonomi Manajemen Universitas Ngurah Rai Denpasar, Bali, \\ Indonesia \\ ${ }^{2}$ e-mail : desak.werdi86@gmail.com
}

\begin{abstract}
ABSTRAKSI
Sumber daya manusia adalah salah satu faktor penting dalam suatu perusahaan agar dapat mencapai tujuan perusahaan yang telah ditetapkan sebelumnya, baik tujuan jangka panjang maupun jangka pendek. dengan mengambil sampel yang berjumlah 87orangkaryawan sebagai responden penelitian. Menggunakan metode pengumpulan data melalui observasi, wawancara, kuesioner dan studi dokumentasi dengan mempergunakan teknik analisis persamaan regresi linear berganda, analisis determinasi, uji t dan uji F dengan bantuan SPSS (Statistical Product and Service Solution) Version 21,0 for Windows. Berdasarkan analisis regresi linear berganda diperoleh $\mathrm{Y}=6,161+$ $0,367 \mathrm{X}_{1}+0,331 \mathrm{X}_{2}$. Menjelaska bahwa ada pengaruh yang positif secara simultan antara lingkungan kerja dan stres kerja terhadap kinerja karyawan bagian produksi. Selanjutnya berdasarka analisis $\mathrm{R}^{2}$ sebesar 0,430 maka nilai kofesien Determinasi diperoleh $\mathrm{D}=, 43$
\end{abstract}

Kata Kunci: Lingkungan Kerja, Stres Kerja, Kinerja Karyawan

\begin{abstract}
Human resource are one of the important factors in a company in order to achieve the company's predetermined goals, both long -term and short-term goals. By taking samples of 87 employees as research responden. Using date collection methods through observation, interview, questionnaire and documentation study using multiple linear regression equation analiysis, determination analysis, $t$ test and F test with SPSS ( Statistical Product and Service Solution) Version 21.0 for Windows. Based on linear regression analysis multiple obtainted $Y 6,161+0,367 X_{1}+0,331 X_{2}$. it is clear that there is simultaneousepositive influence betwen the work environment and work stress on the perfomance of production employees. Furthermore, based on the analysis of $R^{2} O F 0,430$ then the value of kofesien determinasi obtained $D=43 \%$ this means that work environment and work stress simultaneously contribute to employee perfomance of $43 \%$ while the remeaning $57 \%$ is imfluenced by other variabels that are not examined.
\end{abstract}

Keywornd : work Environment, Work Stress, Employee Ferfomance 


\section{PENDAHULUAN}

Manajemen sumberdaya manusia merupakanbagian dari manajemen keorganisasian yang memfokuskan diri pada unsurs umberdayamanusia. Menurut (Siagian, 2014:40) Manajemen Sumber Daya Manusia merupakan unsur terpenting dalam semua organisasi, keberhasilan organisasi mencapai berbagai sasarannya serta kemampuannya menghadapi berbagai tantangan, baik yang bersifat eksternal maupun internal, sangat ditentukan oleh mengelola sumber daya manusia dengan setepattepatnya, Masalah-masalah pengembangan diri, keadilan kewajaran, harapan dan kecocokan pekerjaan dengan karakteristik seseorang, masalah-masalah perilaku organisasi merupakan bagian pengolahan sumber daya manusia yang penting.

Kinerjakaryawan merupakan salah satu faktor penting dalam menentukan fakto berhasil tidaknya perusahaan dan kinerja juga penting karena perusahaan bisa mengetahui sejauh mana kemampuan dari karyawan. Menurut Darodjat (2015) menyatakan bahwa kinerja mempunyai pengertian akan ada tindakan atau kegiatan yang ditampilkan oleh seseorang dalam melaksanakan aktivias tertentu yang menjadi tugasnya.

Lingkungan kerja merupakan komponen yang sangat penting ketika karyawan melakukan aktivitas bekerja, dengan memperhatikan lingkungan kerja yang baik atau menciptakan kondisi kerja yang mampu memberikan motivasi untuk bekerja, maka akan memberikan pengaruh terhadap knerja karyawan (Sunyoto:2015:38).

Kinerjakaryawandapat puladipengaruhiolehstreskerja.
Menurut (Rivai dan Sagala 2011:516)

Stres kerja adalah sesuatu kondisi ketegangan yang menciptakan

ketidak seimbangan fisik dan

fisikis yang mempengaruhi emosi, proses berfikir, dan kondisi seseorang karyawan. Berkaitan dengan pentingnya masalah lingkungan kerja dan stres kerja, maka penulis menentukan objek penelitian pada PT. Bening Big Tree Farm di Desa Sibang Badung, yang merupakan perusahaan bergerak di bidang organik. Kegiatan yang dilakukan PT. Bening Big Tree Farm di Desa Sibang Badung adalah mengolah bahan organik seperti biji kakao yang dijadikan coklat bubuk, coklat batang, coconut yang diolah menjadi blonde dan amber, kacang mente yang diolah menjadi nips, hasil produksi tersebut kemudian akan diekspor ke luar negeri untuk memenuhi kebutuhan konsumen di pasar internasional.

Berdasarkan latar belakang masalah di atas maka masalah yang akan diteliti adalah lingkungan kerja dapat berpengaruh terhadap kinerja karyawan dan kondisi stres kerja karyawan yang berpengaruh pada kinerja karyawan. Dari masalah diatas dapat diperoleh rumusan penelitian sebagai berikut :

a. Bagaimanakah pengaruh lingkungan kerja dan stres kerja secara parsial terhadap kinerja karyawan bagian produksi pada PT. Bening Big Tree Farm di Desa Sibang Badung?

b. Bagaimanakah pengaruh lingkungan kerja dan stres kerja secara simultan terhadap kinerja karyawan bagian produksi pada PT. Bening Big Tree Farm di Desa Sibang Badung? 


\section{METODE PENELITIAN}

Metodelogi penelitian kuantitatif dan kualitatif. Lokasi yang peneliti pilih sebagai lokasi penelitian PT. Bening Big Tree Farm di Desa Sibang Badung. Vafriabel yang digunakan dalam penelitian ini yaitu variabel independen (Lingkungan kerja,Stres kerja) dan variabel dependen (kinerja Karyawan). Teknik pengambilan sampel menggunakan sampling jenuh dikarenakan jumlah karyawanyang tidak begitu besar hanya 87 orang, maka peneliti menggunakan semuanya sebagai responden. Data primer didapatkan dengan cara menyebarkan kuesioner kepada responden dengan menggunakan skala likert sebagai skala pengukurannya. Pada penelitian ini digunakan analisis regresi linier berganda yang bertujuan untuk mengetahui pengaruh variabel independen terhadap variabel dependen

\section{HASIL DAN PEMBAHASAN}

Tabel 3.1 Hasil Analisis Program SPSS 21.0 For Windows Pengaruh Lingkungan Kerja dan Stres Kerja Terhadap Kinerja Karyawan Bagian Produksi Pada PT Bening Big Tree Farm Di Desa Sibang Badung.

\begin{tabular}{lccc}
\hline \multicolumn{1}{c}{ Variabel } & $\begin{array}{c}\text { Koefisien Re- } \\
\text { gresi }\end{array}$ & thitung & Signifikan t \\
\hline Konstanta & 6,161 & 4,194 & 0,000 \\
Lingkungan Kerja & 0,367 & 5,085 & 0,000 \\
$\left(\mathrm{X}_{1}\right)$ & 0,331 & 4,828 & 0,000 \\
Stres Kerja $\left(\mathrm{X}_{2}\right)$ & $=0,656$ & & \\
\hline $\mathrm{R}$ & $=0,430$ & & \\
$\mathrm{R}^{2}$ & $=31,723$ & & \\
F $_{\text {hitung }}$ & $=0,000$ & & \\
Signifikan F & &
\end{tabular}

Sumber :Data dioleh (2018)

1. Analisis Regresi Linear Berganda Analisis ini digunakan untuk mengetahui besarnya pengaruh antara lingkungan kerja dan streskerja secara simultan terhadap kinerja karyawan. Berdasarkan hasil analisis dengan menggunakan program SPSS version 20.0 For Windows pada tabel 3.1 di atas diperoleh nilai $\mathrm{a}=6,161, \mathrm{~b}_{1}=$ 0,367 , dan $b_{2}=0,331$, sehingga dapat dirumuskan persamaan regresi linear berganda adalah $\mathrm{Y}=6,161+0,367 \mathrm{X}_{1}$
$+0,331 \mathrm{X}_{2}$, memberikan informasi bahwa :

a) Nilai a $=6,161$, artinya apabila tidak ada perhatian terhadap lingkungan kerja danstres kerja (konstan), makanilaikinerja karyawan adalah sebesar rata-rata 6,161 .

b) Nilai $b_{1}=0,367$, artinya apabilanilailingkungan kerja meningkat sebesar 1 satuan, maka kinerja karyawan 
mengalami peningkatan sebesar 0,367 dengan asumsi skor stres kerja konstan.

c) Nilai $\mathrm{b}_{2}=0,331$, artinya apabilanilaistres kerja meningkat sebesar 1 satuan, maka nilai kinerja karyawan akan meningkat sebesar 0,331 dengan asumsi nilailingkungan kerja konstan.

2. Analisis Koefisien Determinasi

Analisis koefisien determinasi digunakan untuk mengetahui besarnya kontribusi/sumbangan lingkungan kerja dan stres kerja terhadap kinerja karyawan yang dinyatakan dalam persentase.

Berdasarkan hasil analisis SPSS 21.0 For Windows diperoleh $\mathrm{R}^{2}$ sebesar 0,430, kofesien determinasi D $=43 \%$. Hal ini berarti sumbangan lingkungan kerja dan stres kerja terhadap kinerja karyawan adalah sebesar 43\%. Sedangkan sisanya sebesar $57 \%$ disumbangkan oleh variabel lain yang dalam penelitian ini tidak diteliti.

3. Analisis Statistik uji t (t-test)

Analisis ini digunakan untuk menguji signifikansi pengaruh lingkungan kerja dan stres kerja secara parsial terhadap kinerja karyawan adalah pengaruh positif dan signifikan atau hanya kebetulan saja.

Berdasarkan hasil perhitungan SPSSversion 21.0 for Windowsmaka besarnya nilai $\mathrm{t}_{1 \mathrm{hitung}}$ pada tabel3.1diperoleh besarnya $t_{1 h i-}$ tung adalah sebesar 5,085 dan $\mathrm{t}_{2 \mathrm{hitung}}$ sebesar 4,828yang menunjukkan lebih besar daripada $t_{\text {tabel }}$ sebesar 1,663 (lampiran 7) dengan tingkat signifikansi sebesar 0,000 yang menunjukkan lebih kecil dari 0,05. Sehingga Lingkungan kerja dan stres kerja bepengaruh positif dan signifikan terhadap kinerja karyawan bagian produksi pada PT. Bening Big Tree Farm di Desa Sibang Badung. 4. Analisis Statistik Uji F (F-tes)

Analisis pengaruh Lingkungan Kerja dan Stres Kerja secara simultan terhadap Kinerja Karyawan digunakan alat analisis statistik uji $\mathrm{F}$ (F-test). Analisis ini digunakan untuk menguji signifikansi lingkungan kerja dan stres kerja

Berdasarkan hasil perhitungan SPPSversion21.0 for Windows, maka diperoleh nilai $\mathrm{F}_{\text {hitung }}$ pada tabel 3.1 adalah sebesar 31,723 yang menunjukkan lebih besar daripada $F_{\text {tabel }}$ sebesar 3,11(lampiran 8) dengan tingkat signifikansi sebesar 0,000 yang menunjukkan lebih kecil dari 0,05. Sehingga ligkungan kerja dan stres kerja berpengaruh positif dan signifikan secara simultan terhadap kinerja karyawan bagian produksi pada PT. Bening Big Tree Farm di Desa Sibang Badung.

\section{Pengaruh Lingkungan Kerja Terhadap Kinerja Karyawan Bagian Produksi}

Berdasarka Pengujian secara emperik didapat kofesien regresi sebesar 0,367 nilai t hitung sebesar $5,085 t_{\text {tabel }}$ sebesar 1,663 dan sig 0,000 dengan menggunakan tingkat signifikaansi $5 \%$ maka dapat diartikan bahwa Lingkungan kerja berpengaruh positif dan signifikan terhadap kinerja karyawan bagian produksi pada PT. Bening Big Tree Farm di Desa Sibang Badung. Hasil penelitian memberikan makna bahwa semakin baik lingkungan kerja maka semakin tinggi kinerja karyawan bagian produksi. 
Hasil penelitian ini bersesuaian dengan Tommy Tan (2017) yang menemukan bahwa lingkungan kerja berpengaruh positif dan signifikan terhadap kinerja karyawanPT. Putra Karyasindo Prakarsa Batam.

\section{Pengaruh Stres Kerja Terhadap Kinerja Karyawan Bagian Produksi}

Berdasarka Pengujian secara emperik didapat kofesien regresi sebesar 0,331 nilai t hitung sebesar $4,828 \mathrm{t}_{\text {tabel }}$ Sebesar 1,663 dan sig 0,000 dengan menggunakan tingkat signifikaansi $5 \%$ maka dapat diartikan bahwa Stres kerja berpengaruh positif dan signifikan terhadap kinerja karyawan bagian produksi pada PT. Bening Big Tree Farm di Desa Sibang Badung. Hasil penelitian memberikan makna bahwa semakin baik perhatian Stres kerja maka semakin tinggi kinerja karyawan bagian produksi.

Hasil penelitian ini bersesuaian dengan Tommy Tan (2017) yang menemukan bahwa stres kerja berpengaruh positif dan signifikan terhadap kinerja karyawanPT. Putra Karyasindo Prakarsa Batam.

Pengaruh Lingkungan Kerja dan Stres Kerja Terhadap Kinerja Karyawan Bagian Produksi

Berdasarka Pengujian secara emperik nilai $F_{\text {hitung }}$ sebesar 31,723 $F_{\text {tabel }}$ sebesar 3,11 dan sig 0,000 dengan menggunakan tingkat signifikansi 5\% maka dapat diartikan bahwa Lingkungan kerja dan stres kerja berpengaruh positif dan signifikan terhadap kinerja karyawan bagian produksi pada PT. Bening Big Tree Farm di Desa Sibang Badung. Apabila lingkungan kerja dan stres kerja di tingkatkan secara bersamasama maka kinerja karyawan bagian produksi pada PT. Bening Big Tree Farm di Desa Sibang Badung meningkat.

Hasil penelitian ini bersesuaian dengan Meirina Lubis (2017) yang menemukan bahwa lingkungan kerja dan stres kerja secara bersama-sama atau simultan berpengaruh positif dan signifikan terhadap kinerja karyawanPT. Putra Karyasindo Prakarsa Batam.

\section{Kesimpulan}

Hasil penelitian dan pembahasan yang telah diuraikan, maka dapat ditarik kesimpulan sebagai berikut :

Lingkungan kerja dan stres

kerja berpengaruh positif dan signifikan terhadap kinerja karyawan bagian produksi pada PT. Bening Big Tree Farm Di Desa Sibang Badung. Hal ini ditunjukkan bahwa persamaan garis regresi linier berganda adalah $\mathrm{Y}$ $=6,161+0,367+0,331$.

\section{Besarnya}

kontribusi/sumbangan lingkungan kerja dan stres kerja terhadap kinerja karyawan bagian produksi adalah sebesar 43\%, sedangkan sisanya sebesar $57 \%$ dipengaruhi oleh variabel lain yang tidak diteliti.

Jika dilihat dari pengaruh lingkungan kerja dan stress kerjaterhadap kinerja karyawan bagian produksi pada PT. Bening Big Tree Farm di Desa Sibang Badung sesuai dengan hasil penelitian menunjukkan bahwa nilai $t_{1 h i t u n g}$ sebesar 5,085 dan nilai $t_{2 h i t u n g}$ sebesar 4,828 lebih besar 
dari $t_{\text {tabel }}$ sebesar1,663 serta nilai signifikansi sebesar 0,000 , hal ini menunjukkan bahwa "lingkunhan kerja dan stres kerja berpengaruh positif dan signifikan secara parsialterhadap kinerja karyawan bagian produksi pada PT. Bening Big Tree Farm di Desa Sibang Badung.

Berdasarkan hasil pengaruhlingkungan kerja dan stres kerja terhadap kinerja karyawan bagian produksi pada PT. Bening Big Tree Farm di Desa Sibang Badung menunjukkan bahwa nilai $F_{\text {hitung }}$ sebesar31,723lebih besar daripada $F_{\text {tabel }}$ sebesar 3,11 dan nilai signifikansi sebesar 0,000 lebih kecil dari 0,05, hal ini menunjukkan bahwa "Lingkungan kerja dan stres kerja berpengaruh positif dan signifikan secara simultan terhadap kinerja karyawan bagian produksi pada PT. Bening Big Tree Farm di Desa Sibang Badung.pada PT. B Bening Big Tree Farm di Desa Sibang Badung

\section{Saran}

Hendaknya perusahaan lebih memperhatikan lingkungan kerja karyawan seperti ventilasi karena dalam menjalankan kegiatan produksi sangat diperlukan sirkulasi udara, didalam sebuah pabrik jika sirkulasi udara tidak memadai maka akan mempengaruhi kinerja karyawan karena dalam lingkungan sebuah pabrik situasinya sangat panas.

Bagi karyawan diharapkan mampu menjalin kerjasama baik itu dalam satu shift atau shift yang lain jika ada kerjasama yang baik dan komunikasi yang baik maka target produksi akan terselesaikan tepat waktu sesuai yang ditetapkan perusahaan dan suasana hati dalam bekerja akan terasa nyaman dan senang karena hubungan antara sesama karyawan berlangsung harmonis. Karyawan juga diharapkan mampu menyesuaikan peraturan yang disesuaikan oleh perusaan karena yang namanya peraturan harus ditaati.

Untuk penelitian selanjutnya dengan topik yang sama, disarankan menggunakan metodelogi penelitian dan objek penelitian yang berbeda agar dapat dilihat perbedaan dan persamaan antara penelitian ini dengan penelitian yang dilakukan sehingga menambah pengetahuan bagi banyak pihak.

\section{Daftar Pustaka}

Darodjat, Tubagus Achmad. 2015. Konsep - Konsep Dasar Management Personalia masa kini. Bandung : PT. Refika Aditama

Kotler, K.(2009). Manajemen Pemasaran 1.Edisi ketiga belas. Jakarta: Erlangga

Kotler, P.(2004). Manajemen Pemasaran.Edisi millennium.Jakarta: PT. Prenhallinda. Jakarta

Hasibuan, H.(2014). Manajemen Sumber Daya Manusia.Edisi Revisi. Jakarta: PT.BumiAksara.

Sunyoto, Danang. 2015. Manajemen dan Pengembangan Sumber Daya Manusia (Cetakan Pertama). Yogyakarta: CAPS (Center for Academic Publishing Service) 
Sugiyono. 2014. Metode Penelitian

Kuantitatif Kualitatif dan R\&D. Badung: Alfabeta.

Sondang P. Siagian. 2014. Manajemen Sumber Daya Manusia. Jakarta : Bumi Aksara.

Rivai, Veithzal dan Sagala, Ella Jauvani. 2011. Manajemen Sumber Daya Manusia untuk Perusahaan dari Teori ke Praktik. Jakarta: PT Raja Grafindo. 